\title{
COMPARISON OF OLD AND NEW CLONES OF POTATO NUCLEAR SEED STOCKS FOR TUBER UNIFORMITY IN THE GREENHOUSE
}

\author{
Gulsum OZTURK ${ }^{*}$, Zihin YILDIRIM ${ }^{1}$ \\ ${ }^{1}$ Ege University, Faculty of Agriculture, Department of Field Crops, Bornova-Izmir, TURKEY \\ *Corresponding author: gulsum.ozturk@ege.edu.tr
}

Received: 25.02.2014

\begin{abstract}
The plantlets of old and new clones micropropagated from nuclear seed stocks were grown in the greenhouse to compare their tuber uniformity. The old and new clones nested in cultivars Agria, Hermes and Granola, were grown in Completely Randomized Plots design in the fall, 2012 and in the winter, 2013. The tuber characteristics were measured and the standard analyses of variance technique were applied and the regression coefficients of the means of new clones on the means of the old clones were estimated for tuber number, single tuber weight (g), single plant yield (g), plot yield (g), tuber width and tuber length. The $\mathrm{F}$ values for the clone type and clone were non significant indicating the uniformity of the means of the old and new clones. In addition, the $b$ values of the regression of the means of the new clones on the means of the old clones were found to be equal to 1 supporting the hypothesis of the uniformity of the old clones and new clones for tuber characteristics.
\end{abstract}

Keywords: Basic seed, clone, potatoes, regression coefficient, uniformity

\section{INTRODUCTION}

The basic seed is the first step in a successful seed potato production programme to distribute healty seed tubers to the growers (Bus and Wustman, 2007). Meristem cultures have been used in obtaining virus free basic seed stocks in the seed potato programs (Yildirim and Yildirim, 1984; Ranalli et al., 1990; Regan et al., 1995; Yildirim et al., 1995; Ražukas, 2002; Bus and Wustman, 2007; Pruski, 2007; Struik, 2007; Sharma et al., 2013).

Since several factors such as fungi, bacteria and viruses are carried through the seed tubers, constructing nuclear seed stocks are the first step and requires in vitro techniques (Regan et al., 1995; Ahloowalia, 1999; Nielsen et al., 2007; Pruski, 2007). The seed stocks were obtained in vitro and they were maintained in the laboratory as nuclear seed stocks. There have been some arguments about keeping the nuclear seed stocks for several years in the laboratory and sampling meristem plants from them to produce mini tubers used in the elit seed production. Although some studies demonstrated that the basic seed stocks need to be renewed every year (Rosenberg et al., 2010), this practice has not been widely supported.

In this study, Nuclear Seed stocks obtained by meristem cultures in a National Seed Potato program in 2007 (Caliskan et al., 2010) and maintained in the laboratory for several years were compared with the new meristem clones constructed from their meristems. In accord with the purpose of this study, the uniformity of the old and new clones for the tuber characteristics could be studied (1) by evaluating the F values pertinent to the variation of the clones based on the ANOVA table. If the hypothesis of $\mathrm{H}_{\mathrm{o}}$ : $\mathrm{m}_{\text {old }}=\mathrm{m}_{\text {new }}$ is valid the $\mathrm{F}$ values will be non significant for the tuber characteristics indicating their uniformity (2) by estimating the regression coefficient of the means of the new clones on the means of old clones. If the $b$ values are equal to 1 , there should be a close correspondence between the means of the old and new clones.

\section{MATERIALS AND METHODS}

The study was conducted in the Tissue Culture Laboratory and the Greenhouse of the Field Crops Department of the Agricultural Faculty of the Ege University, Izmir, Turkey in 2012 and 2013. The nuclear seed stocks of three potato cultivars, Agria, Hermes, Granola, had been established through the meristem cultures in 2007 and they were renewed by subculturing . The new clones originated from the tubers of the meristem samples taken from the nuclear seed stocks were obtained in 2012. The meristem plantlets were increased by nodal cuttings for the new and old clones. Then the new clones and the old clones of the original seed stocks were grown in the greenhouse to compare their tuber characteristics.

The old meristem stocks have been sub-cultured since 2007 and the plantlets propagated from these stocks were used for mini tuber production in the National Research Project supported by the Scientific and Technological 
Research Council of Turkey. Sprouts of potato tubers were cultured in the MS (Murashige and Skoog, 1962) medium supplemented with Auxin, Cytokinin and Gibberelline as described as Ozturk and Yildirim (2011). The in vitro meristem plantlets were multiplied by nodal cuttings (Yildirim, 1995) and the meristems and cuttings were micro propagated in certain periods in the laboratory for their maintenance. The new meristem clones were composed of in vitro tubers from the meristem plants sampled from the seed stocks taken in 2012.

\section{Production of mini tubers in the greenhouse}

The old and new meristem clones described above obtained from in vitro plantlets were grown in two successive growing periods in the greenhouse. They were transferred to the plastic cups in September, 2012 and in February, 2013. Three clones nested in each of the three cultivars were grown in the Completely Randomized Design (CRD) with three replications. One plot consisted of 10 plantlets in plastic cups. Plants of two types of meristem clones were harvested in January, 2012 and in May, 2013. At the harvest, plot yield and tuber number were recorded. Following the harvest, tuber width $(\mathrm{cm})$ and tuber length $(\mathrm{cm})$ were measured on random samples of five mini tubers. Later the tuber number plant ${ }^{-1}$ and single plant yield were calculated.

\section{Statistical analyses}

Analyses of variance were run on the data of the traits measured by assuming clones nested in cultivars. The F values for the characteristics were obtained and the regression coefficients for the association between new clones (Y) and old clones (X) were estimated following the prosedures described by Steel et al. (1997).

\section{RESULTS AND DISCUSSION}

\section{Mini tuber characteristics of the old and new meristem clones}

Three old and three new clones nested in three cultivars were grown in the greenhouse in the fall, 2012 and in the spring, 2013. The mini tubers of 9 old and 9 new clones harvested were measured for tuber characteristics in order to compare the uniformity of the old and new meristem clones. The F values of the 6 tuber characteristics are shown in Table 1.

Table 1. The F values of the yield and tuber characteristics from the ANOVA combined over 2012 and 2013.

\begin{tabular}{lllllll}
\hline $\begin{array}{l}\text { Source of } \\
\text { Variation }\end{array}$ & $\begin{array}{l}\text { Tuber Number } \\
\text { Plant }^{-1}\end{array}$ & $\begin{array}{l}\text { Single Tuber } \\
\text { Weight }(\mathbf{g})\end{array}$ & $\begin{array}{l}\text { Single Plant } \\
\text { Yield }(\mathbf{g})\end{array}$ & $\begin{array}{l}\text { Plot Yield } \\
(\mathbf{g})\end{array}$ & $\begin{array}{l}\text { Tuber } \\
\text { Width }(\mathbf{c m})\end{array}$ & $\begin{array}{l}\text { Tuber } \\
\text { Length }(\mathbf{c m})\end{array}$ \\
\hline Time & $57.75^{* *}$ & $16.09^{* *}$ & $76.60^{* *}$ & $76.60^{* *}$ & $4.43^{* *}$ & $15.33^{* *}$ \\
Cultivars & $295.85^{* *}$ & $80.29^{* *}$ & $356.68^{* *}$ & $356.68^{* *}$ & $25.05^{* *}$ & $28.00^{* *}$ \\
Type of clone & $0.726^{\mathrm{ns}}$ & $1.494^{\mathrm{ns}}$ & $1.453^{\mathrm{ns}}$ & $1.453^{\mathrm{ns}}$ & $0.143^{\mathrm{ns}}$ & $0.604^{\mathrm{ns}}$ \\
Clone & $1.70^{\mathrm{ns}}$ & $0.58^{\mathrm{ns}}$ & $0.94^{\mathrm{ns}}$ & $0.94^{\mathrm{ns}}$ & $0.25^{\mathrm{ns}}$ & $1.35^{\mathrm{ns}}$ \\
\hline
\end{tabular}

*: old and new clones

**: significant at the $\mathrm{p} \leq 0.01$

ns: non significant

It could be seen in Table 1 that the variation for the type of clone was not significant for all the tuber characteristics studied. The variation of clones nested in cultivars had also non significant $F$ values. On the other hand cultivars and time of growing had significant $F$ values at the $p \leq 0.01$ probability level for all the traits.

Since the F values for the type of clone (old and new) and clone were non-significant we can accept the hypothesis that there was no difference between the means of the clones nested in cultivars for the 6 tuber characteristics. These results indicated the uniformity of the tuber characteristics of the clones originated from the old and new cultures.

Although the non-significant $\mathrm{F}$ values obtained for the old and new clones, the means of the old and new clones of 3 cultivars and the regression coefficients between them assuming the new clones as dependent variable are presented in Table 2.

Table 2 shows the means of the tuber characteristics of the old and new clones. The means of the 9 clones from Agria (3), Hermes (3) and Granola (3) had the uniformity confirmed by the non-significant $F$ values mentioned above. The regression coefficients between the means of the old and new clones were found to be 1 indicating a one to one correspondence between the means of old and new clones. The uniformity of the old and new clones was also supported by the $b$ values, so it could be accepted that under the greenhouse conditions, the mini tubers produced from old and new clones were uniform for the 6 tuber characteristics studied. The uniformity of the old and new clones for the tuber traits could also be observed in figures $1,2,3,4,5$ and 6 .

Since the callus formation was not observed due to the fast multiplication of the meristems, the genotypic variation among the meristem plants used in seed potato tuber production could not be expected. As a result, the uniformity of the tuber characteristics has continued for several steps of the multiplication. Ahloowalia (1999) reported that mini tubers of cultivars were similar to parents for uniformity of tuber and plant characteristics. Wright (1983) stated that variation observed for tuber traits within cultivars were due to other factors. Among them pathogens could be controlled, since their effect could be minimized due to strict control mechanism in the laboratory and also in the greenhouse. 
Table 2. The means of the old and new clones for tuber characteristics

\begin{tabular}{|c|c|c|c|c|c|c|c|c|c|c|c|c|}
\hline \multirow[t]{2}{*}{ Clones } & \multicolumn{2}{|c|}{$\begin{array}{c}\begin{array}{c}\text { Tuber Number } \\
\text { Plant }^{-1}\end{array} \\
\end{array}$} & \multicolumn{2}{|c|}{$\begin{array}{c}\begin{array}{c}\text { Single Tuber } \\
\text { Weight }(g)\end{array} \\
\end{array}$} & \multicolumn{2}{|c|}{ Single Plant Yield (g) } & \multicolumn{2}{|c|}{$\begin{array}{c}\text { Plot Yield } \\
(\mathrm{g})\end{array}$} & \multicolumn{2}{|c|}{$\begin{array}{c}\text { Tuber Width } \\
(\mathrm{cm})\end{array}$} & \multicolumn{2}{|c|}{$\begin{array}{c}\text { Tuber Length } \\
(\mathrm{cm})\end{array}$} \\
\hline & $\begin{array}{c}\text { Old } \\
\text { merist } \\
\text { em }\end{array}$ & $\begin{array}{l}\text { New } \\
\text { meristem. }\end{array}$ & $\begin{array}{c}\text { Old } \\
\text { meristem }\end{array}$ & $\begin{array}{c}\text { New } \\
\text { meristem }\end{array}$ & $\begin{array}{c}\text { Old } \\
\text { meristem }\end{array}$ & $\begin{array}{c}\text { New } \\
\text { meristem }\end{array}$ & $\begin{array}{c}\text { Old } \\
\text { meristem }\end{array}$ & $\begin{array}{c}\text { New } \\
\text { meristem }\end{array}$ & $\begin{array}{c}\text { Old } \\
\text { meristem }\end{array}$ & $\begin{array}{c}\text { New } \\
\text { meristem }\end{array}$ & $\begin{array}{c}\text { Old } \\
\text { meristem }\end{array}$ & $\begin{array}{c}\text { New } \\
\text { meristem }\end{array}$ \\
\hline Agria-1 & 2.8 & 2.7 & 2.8 & 3.0 & 7.9 & 8.2 & 79.1 & 81.7 & 1.8 & 1.8 & 2.5 & 2.5 \\
\hline Agria-4 & 2.7 & 2.7 & 2.9 & 2.9 & 7.7 & 7.8 & 77.1 & 77.9 & 1.8 & 1.8 & 2.4 & 2.5 \\
\hline Agria-5 & 2.7 & 2.8 & 3.0 & 2.9 & 8.0 & 8.0 & 79.9 & 80.4 & 1.8 & 1.8 & 2.5 & 2.5 \\
\hline Hermes-36 & 2.0 & 1.9 & 2.2 & 2.3 & 4.4 & 4.6 & 43.5 & 46.7 & 1.6 & 1.6 & 2.2 & 2.3 \\
\hline Hermes-27 & 1.8 & 1.9 & 2.2 & 2.2 & 4.2 & 4.3 & 42.1 & 42.5 & 1.6 & 1.6 & 2.3 & 2.2 \\
\hline Hermes-10 & 1.9 & 1.9 & 2.2 & 2.2 & 4.3 & 4.1 & 42.6 & 41.3 & 1.6 & 1.6 & 2.2 & 2.2 \\
\hline Granola-48 & 2.4 & 2.3 & 2.2 & 2.2 & 5.4 & 5.3 & 54.0 & 52.5 & 1.6 & 1.6 & 2.3 & 2.3 \\
\hline Granola-53 & 2.4 & 2.4 & 2.2 & 2.2 & 5.1 & 5.4 & 51.1 & 53.9 & 1.6 & 1.6 & 2.2 & 2.2 \\
\hline Granola-12 & 2.5 & 2.4 & 2.0 & 2.2 & 5.2 & 5.4 & 52.0 & 53.5 & 1.6 & 1.6 & 2.3 & 2.3 \\
\hline $\begin{array}{l}\text { Regression } \\
\text { coefficient } \\
\text { (b) }\end{array}$ & \multicolumn{2}{|c|}{$0.96^{\mathrm{ns}}$} & \multicolumn{2}{|c|}{$0.93^{\mathrm{ns}}$} & \multicolumn{2}{|c|}{$0.99^{\mathrm{ns}}$} & \multicolumn{2}{|c|}{$0.99^{\mathrm{ns}}$} & \multicolumn{2}{|c|}{$1.0^{\mathrm{ns}}$} & \multicolumn{2}{|c|}{$0.98^{\mathrm{ns}}$} \\
\hline
\end{tabular}

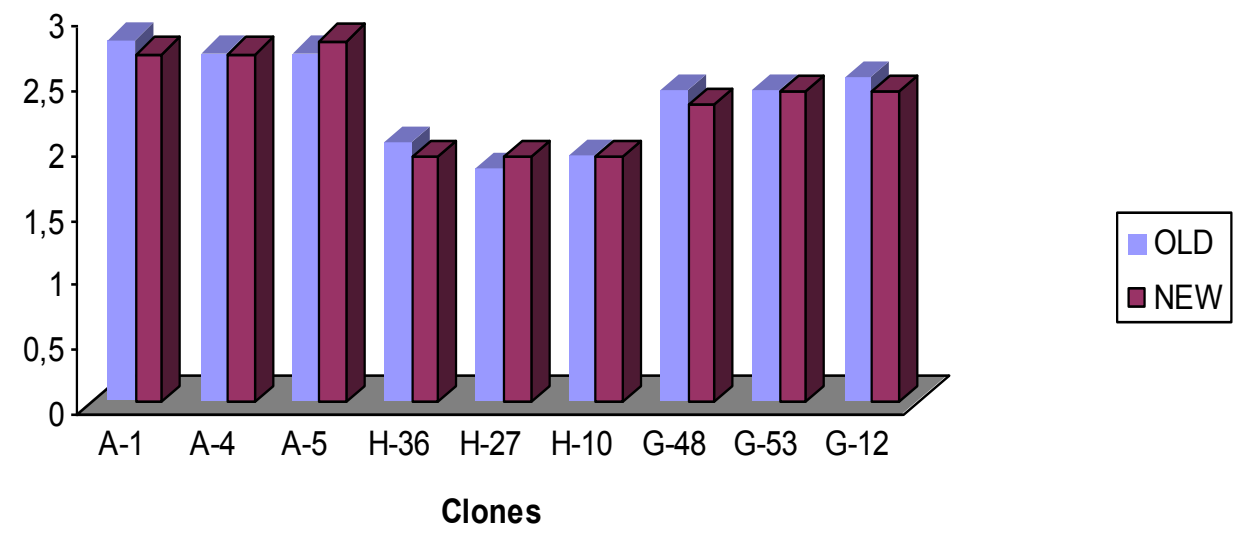

Figure 1. Histograms of tuber number of the mini tubers of old and new clones combined over 2012 and 2013. A: Agria, H: Hermes. G: Granola

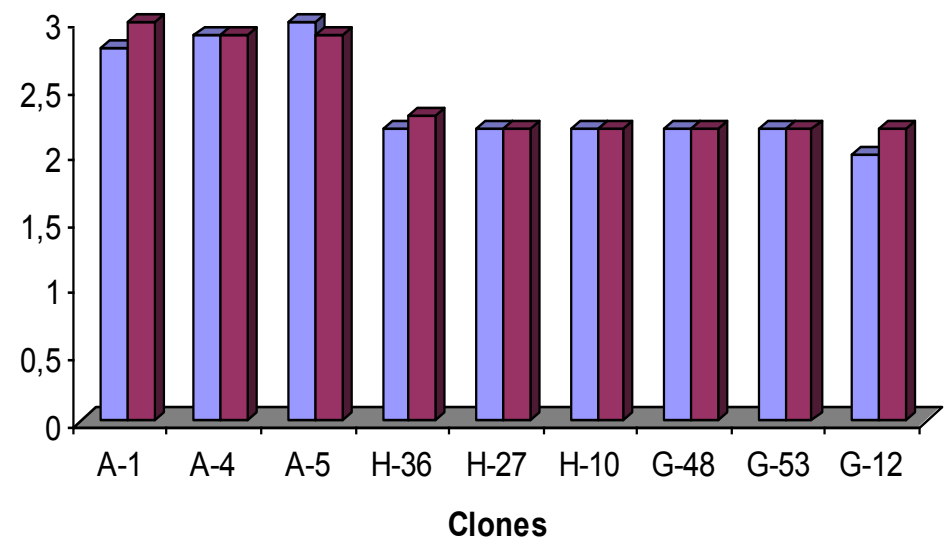

Figure 2. Histograms of single tuber weight (g) of the mini tubers of old and new clones combined over 2012 and 2013. A: Agria, H: Hermes. G: Granola 


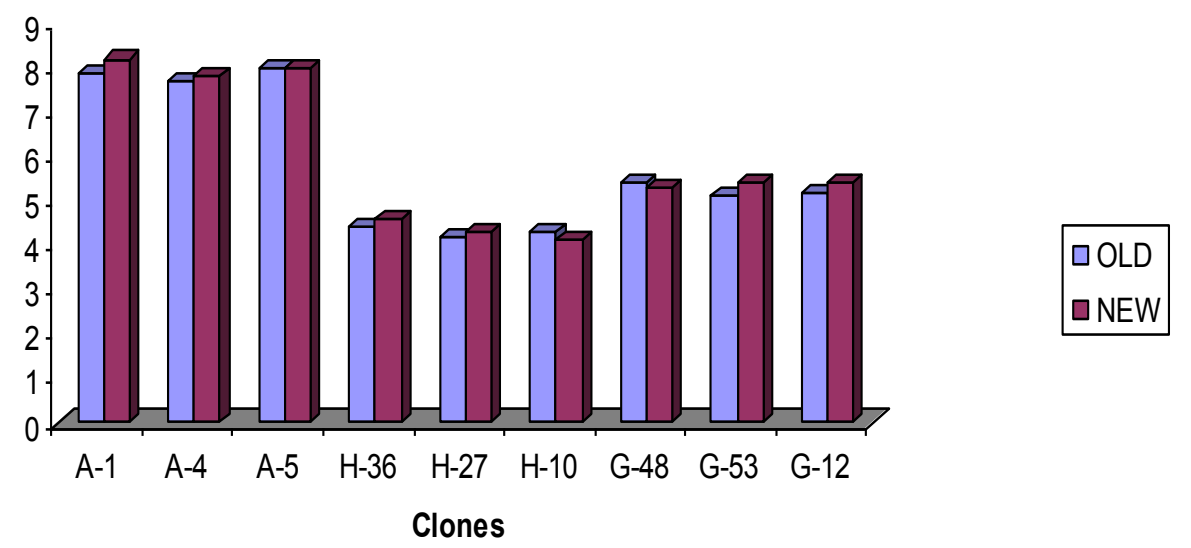

Figure 3. Histograms of single plant yield ( $\mathrm{g}$ ) of the mini tubers of old and new meristem clones combined over 2012 and 2013 . A: Agria, H: Hermes. G: Granola

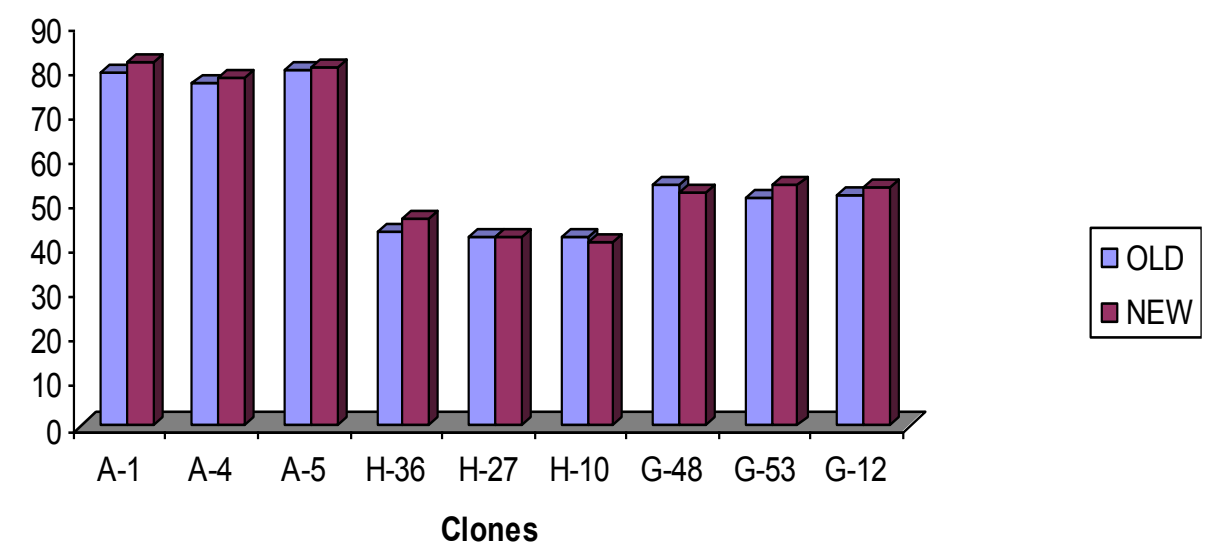

Figure 4. Histograms of plot yield (g) of the mini tubers of old and new clones combined over 2012 and 2013. A: Agria, H: Hermes. G: Granola

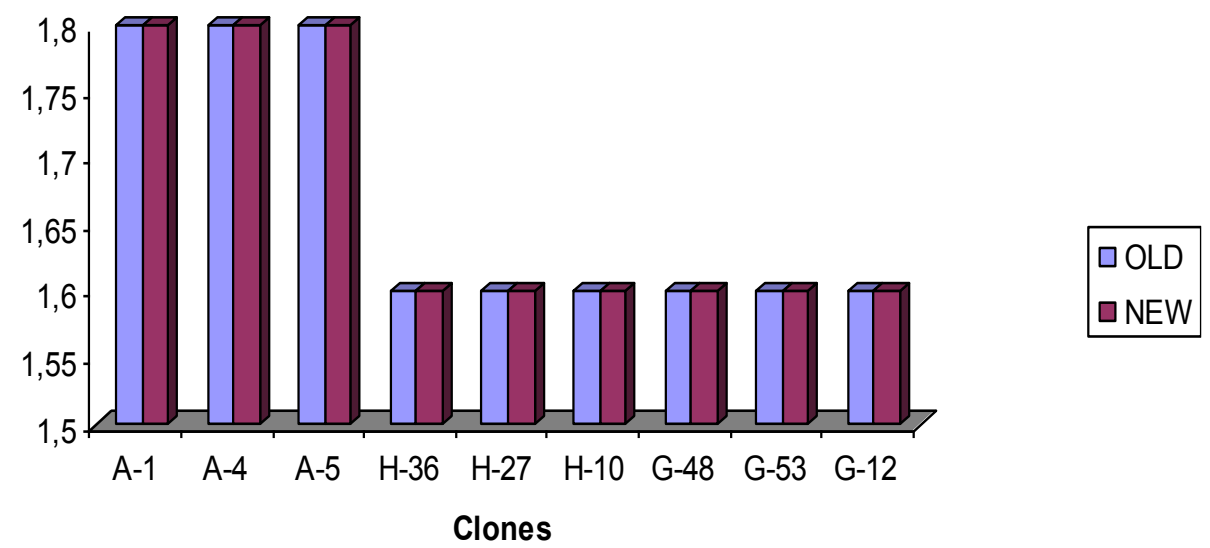

Figure 5. Histograms of tuber width $(\mathrm{cm})$ of the mini tubers of old and new clones combined over 2012 and 2013. A: Agria, H: Hermes. G: Granola 


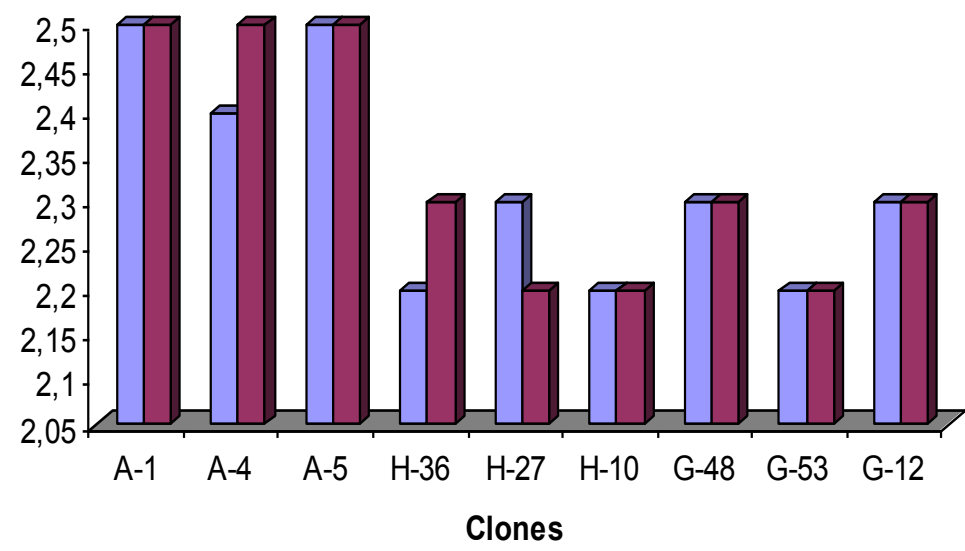

Figure 6. Histograms of tuber length $(\mathrm{cm})$ of the mini tubers of old and new meristem clones combined over 2012 and 2013 . A: Agria, H: Hermes. G: Granola

The tuber uniformity of the clones has been reported as consistent in the successive field multiplication stages of the mini tubers (Wright, 1983; Niemira et al., 1995; Kenneth and Charlton, 2004; Coltman, 2012). During the greenhouse multiplication of meristem plants, tuber number per plant was reported as 2 for Agria (Hassanpanah and Khodadadi, 2009) which was a little lower than the value obtained in this study.

Nielsen et al. (2002) reported the stability of Granola meristem clones tested several years in the field. Therefore the uniformity found in this study could be accepted in agreement with their result.

Balali et al. (2008) reported significant variation for planting time and genotype. The significant $F$ values for planting time and for genotypes obtained in this study confirmed their report. The mini tuber yield of cultivars were found to be significantly different in this study conforming the reports of several workers (Powel et al., 1989, Venkatasalam et al., 2011 and Sharma et al., 2013).

In Turkey, there has been a steady problem in managing the mini tuber production which causes a significant impact on the seed potato growers. A major factor for this constraint was reported as sanitary problems and pathogen infection in the field (Caliskan et al., 2010). Since the strict controlled conditions were maintained in the greenhouse, these type of infections have not be observed. Therefore further problems to be encountered in the field multiplication stage should be resolved by selecting suitable field and management practices.

\section{CONCLUSION}

The uniformity of the seed stocks in the laboratory and the clones sampled from them were almost identical for the tuber characteristics. Therefor to achieve a successful mini tuber distribution in Turkey, the problems encountered during the field multiplication of mini tuber should be solved.

\section{ACKNOWLEDGEMENT}

The authors would like thank to Professor Rajesh K. Rana, Shimla, India, editor of Potato Journal for his kind and valuable help in evaluating the manuscript.

\section{LITERATURE CITED}

Ahloowalia, BS. 1999. Production of mini-seed tubers using a modular system of plant micropropagation. Potato Research. 42:569-575.

Balali, GR., MR. Hadi, P. Yavari, H. Bidran, AC. Nadeni, A. Eshami. 2008. Effect of pot size, planting date and genotype on mini tuber production of Marfona potato cultivar. Afri Jour Biyotechnology. 7: 1265-1270.

Bus, CB. and R. Wustman. 2007. Seed tubers. Potato Research. 50: 319-322.

Caliskan, MF., H. Onaran, H. Arioglu. 2010. Overview of the Turkish potato sector: Challenges, achievements and expectations. Potato Research. 53: 255-266.

Coltman, RR. 2012. Optimization of nuclear seed production: seed generations and potato crop productivity. Wisconsin Vegetable Production, vegetables.wisc.edu/ 11 Nov 2013.

Hassanpanah, D. and M. Khodadadi. 2009. Study the plantlet age effect and planting beds on Agria potato mini-tuber production under in vivo condition. Journal of Biological Sciences. 9(3): 243-248.

Kenneth, AR. and BA. Charlton. 2004. Effects of prenuclear mini tuber seed size on production of wallowa russet seed. The annual report Klamath Experiment Station, Klamath Falls, Oregon, U.S.A.

Murashige, T. and M. Skoog. 1962. A revised medium for rapid growth and bioassay with tobacco cultures. Physiol. Plant 15: 473-479.

Niemira, BA, GR. Safir, R. Hammerschmidt, GW. Bird. 1995. Production of prenuclear minitubers of potato with peatbased arbuscular mycorrhizal fungal inoculum. Agronomy Journal. 87(5):942-946.

Nielsen, SL, H. Bang, K. Kotkas, K. Kristensen, JP. Palohuhta, K. Tolstrup. 2002. Stability of potato meristem clones. TemaNord 2002:555 Nordic Council of Ministers Copenhagen pp 20-25.

Nielsen, SL, H. Bang, K. Kotkas, K. Kristensen, JP. Palohuhta, V. Rosenberg, K. Tolstrup. 2007. Variation of growth and disease characters between clones of potato (Solanum tuberosum L). Potato Research. 50: 97-114. 
Ozturk, G. and Z. Yildirim. 2011. Uniformity of potato mini tubers derived from meristem cultures of nuclear seed stocks. Turk J Field Crops 16: 149-152.

Powel, W., J. Brown, PDS. Caligari, 1989. Variability in responce of potato cultivars to micro-propagation II. Subsequent field performance. Ann. Appl. Biol. 115: 123128.

Pruski, K. 2007. In vitro multiplication through nodal cuttings. Potato Research. 50: 293-296.

Ranalli, PE. Forti, G. Mandolino, B. Casarini. 1990. Imrowing production and health of seed potato stocks in Italy. Potato Research. 33: 377-387.

Ražukas, A. 2002. Effect of genotype on distribution of diseases and viruses in potato. Biologija, ISSN: 1392-0146. Nr.1.

Regan, DR., V. Souza Machado, SMM. Alam, A. Alı. 1995. Greenhouse production of potato (Solanum tuberosum L. cv. Desire) seed tubers using in vitro plantlets and rooted cuttings in large propagation beds. Potato Research. 38: 6168.

Rosenberg, V., M. Sarekanno, K. Kotkas, V. Vasar, A. Ojararnd. 2010. Variation of agronomic traits of potato somaclones produced by meristem culture. Agronomy Reasearch. 8, 697704.
Sharma, A.K., E.P. Venkatasalam, V. Kumar. 2013. Potato minituber production during main and off crop seasons in high hills of North-Western Himalaya.Potato J. 40(1): 29.37.

Steel, RGD., JA. Torrie, DA. Deckey. 1997. Principles and procedures of statistics. A. Biometrical Approach $3^{\text {rd }}$ Edi, Mc Graw Hill Book.INC.N.Y.

Struik, PC. 2007. Mini tubers. Potato Research. 50: 305-308

Venkatasalam, E.P., J. Latawa, S. Sarma, S. Sarma, A.K.. Sarma, S. Sarma, R. Patial, S. Singh. 2011. In vitro and in vivo performance of potato cultivars for different seed production systems. Potato J. 38(2): 149-154.

Wright, NS. 1983. Uniformity among virus-free clones of ten potato cultivars. American Potato Journal. 60: 381-388.

Yildirim, MB. and Z. Yildirim. 1984. Virus free potato seed production by meristem culture. The Journal of Agricultural Faculty of Ege University. 21:45-50 (in Turkish).

Yildirim, MB., Z. Yildirim, C. Caliskan, O. Caylak. 1995. Production of healty potato seed through meristem culture. Final Report of Research of Project 91-ZRF-064 (in Turkish)

Yildirim, Z. 1995. Microtuber production in potato (Solanum tuberosum L). The Journal of Agricultural Faculty of Ege University. 32: 73-77 (in Turkish). 